\title{
INFLUENCE OF MANAGEMENT SYSTEMS ON LAMBS PERFORMANCE AND CARCASS CHARACTERISTICS IN OSSIMI SHEEP
}

\author{
T. M. M. Hassan \\ Department of Animal Production, Faculty of Agriculture, Banha University, Egypt \\ Tamer.Mohamed@fagr.bu.edu.eg
}

\section{SUMMARY}

This experiment was carried out at the experimental farm, Faculty of Agriculture at Moshtohor, Banha University, Egypt, on 20 Ossimi male lambs to investigate the effect of management systems (10 lambs in intensive and 10 lambs in semi-intensive management system) on lambs live performance, feed conversion and economical feed efficiency in addition to lambs carcass traits. The results showed that management systems showed a significant effect on lamb's live performance and carcass traits. Lambs growth performance of intensive management system group was better than semi-intensive management system in final live body weight (43.50 vs.38.80 kg), average daily gain (0.238 vs. 0.192 $\mathrm{kg} /$ day) and lambs economical feed efficiency (1.43 vs. 1.24), respectively. Hot carcass weights, dressing percent, prime and second cuts of lambs in intensive management system were significantly higher than lambs subjected semi-intensive management system.

Keywords: Management, lambs, performance, carcass

\section{INTRODUCTION}

Sheep constitute an important component of livestock production in tropics and subtropics. Ossimi sheep and their crosses are an important local breed groups in Egypt which they dominate in the Upper Delta and the southern part of the Nile valley (Yehia, 2006). Meat yield is an output of lamb's growth (Ali, 2007). The grazing system with supplement had the advantage to allow producing light lambs saving a high amount of concentrates but achieving similar or even greater ADG to that registered in dry lot lambs (Carrasco et al., 2009). Alternative production systems are available to complement breed and forage resources that can maximize profitability by improving productivity and carcass characteristics of the sheep operation (Dimsoski et al., 1999).

The objectives of the current experiment were to investigate the effect of management systems (intensive and semi-intensive management system) on lambs performance (body weight, average daily gain, feed conversion and economical feed efficient) and lambs carcass traits at the end of experiment during three months of feeding period.

\section{MATERIAL AND METHODS}

\section{Experimental Animals:}

Twenty Ossimi male lambs at six months of age and average body weight of (22.6-23.5 kg) belonged to the flock raised in the experimental farm of the Faculty of Agriculture at Moshtohor, Banha University were randomly divided into two equal management feeding system groups (ten lambs in the intensive management system and ten in the semi-intensive management system).

Male lambs belong to intensive management system produced from ewes under intensive mating system (three lambing in two years) with supplemented feeding of concentrate mixture while, male lambs belong to semi-intensive management system produced from wes under semi-intensive mating system (one lambing by year).

\section{Feeding Management Systems:}

Lambs under the intensive management system were raised permanently in the pen and permitted some hours of the day to move to a yard attached with the pen. It was not permitted for these lambs either to go out of the pen or to graze. Lambs belonged to intensive management system group were individually feeding wheat straw and Egyptian clover ad libitum, while the concentrate feed mixture was allowed according to National Research Council (N.R.C., 1985) recommendation based on the animal live body weight (Table 2). On the other hand, the lambs raised under the semi-intensive management system were allowed to go out for grazing Egyptian clover about 5 hours per day and feeding wheat straw ad libitum. Diets were offered twice daily in equal quantities at $8.00 \mathrm{am}$ and $4.00 \mathrm{pm}$ and estimated for each of the two groups every day. Both of the consumed diets and refusals, if any, were recorded daily.

All lambs were individually weighed to the nearest $\mathrm{kg}$ at the start of the feeding period and thereafter weekly in the morning before feeding and drinking till the end of feeding period. 
Feed conversion was recorded by this equation $=$ feed/gain $\mathrm{kg}$ (Hassan, 2011).

Economical feed efficiency $=$ benefit of weight gain (LE)/cost of feed consumed (LE) Based on price of the ingredients in the market during the experimental period. The prices were: concentrate feed mixture, rice straw and

Egyptian clover 3000 (LE)/ton and the live weight gain 30 (LE) $/ \mathrm{kg}$ (Hassan, 2011).

\section{Feed Intake:}

The experimental period lasted for three months. The chemical analysis of the feeding ration used in lambs feeding is presented in Table (1)

Table 1. Chemical analysis of the ration used in lambs feeding (\% on DM basis)

\begin{tabular}{lcccccc}
\hline \multirow{2}{*}{ Items } & \multicolumn{5}{c}{ Composition on DM basis \% } \\
\cline { 2 - 7 } & DM & CP & CF & EE & NFE & Ash \\
\hline Concentrate feeding mixture & & & & & & \\
(CFM)* & 90.45 & 14.11 & 5.22 & 12.31 & 62.98 & 5.38 \\
Egyptian clover & 18.34 & 4.57 & 4.57 & 0.65 & 71.22 & 17.99 \\
Wheat straw & 95.95 & 2.56 & 45.92 & 1.60 & 38.59 & 11.33 \\
\hline
\end{tabular}

*CFM consisted of cotton seed cakes $35 \%$, wheat bran $33 \%$ yellow corn $22 \%$, rice bran $4 \%$, molasses $3 \%$, calcium carbonate $2 \%$ and sodium chloride $1 \%$.

Table 2. Daily feed intake of concentrate mixture dry matter per head $(\mathrm{kg})$ according to N.R.C. (1985)

\begin{tabular}{lllllllllllll}
\hline Lamb weight $(\mathrm{kg})$ & 10 & 20 & 25 & 30 & 35 & 40 & 45 & 50 & 55 & 60 & 65 & 70 \\
\hline $\begin{array}{l}\text { concentrate } \\
\text { mixture }(\mathrm{kg})\end{array}$ & 0.6 & 1.0 & 1.2 & 1.3 & 1.4 & 1.6 & 1.7 & 1.8 & 1.9 & 2.0 & 2.3 & 2.5 \\
\hline
\end{tabular}

Mineralized salt and clean water were available to animals all the time. Lambs were subjected to the routine vaccination program against infectious diseases and also were injected or drenched against internal parasites. At the same time, the experimental animals were sprayed by the suitable pestsides when needed.

\section{Carcass Data:}

At the end of the feeding period 6 male lambs from each of the management system group (intensive and semi-intensive management system) were slaughtered for carcass evaluation. Lambs were fasted 18 hours before slaughter (El-Mahdy et al., 2000).

After complete bleeding, lambs were skinned and dressed out, then hot carcass weight after removing all internal organs, was recorded. Weights of the following organs: heart, spleen, kidneys, liver, lungs and trachea, the two testes in addition to head, the four legs, skin and digestive tract (stomach and intestine) full and empty were recorded to the nearest g. For each slaughtered lambs, weights of hot carcass with and without offal's (heart, spleen, kidneys, liver and testes) and of all available prime (round, loin, rack and shoulder) and second (neck, brisket, flank and tail) cuts were recorded.

Dressing percentage was calculated using the following formulae (Hassan, 2011).

* Empty body weight = body weight after complete bleeding and eviscerated contains of digestive tract.

$$
\text { Dressing } \%=\frac{\text { Carcass weight }+ \text { weight of (liver }+ \text { heart }+ \text { kidneys }+ \text { spleen }+ \text { testes })}{\text { Empty body weight* }} \times 100
$$

\section{Statistical analysis:}

Statistical analysis was carried out by using the least squares procedures for analyzing the data as described by SAS (2004).The Statistical model used to underlay the least squares analysis of variance was as follows:

$\mathrm{Yij}=\mu+\mathrm{S}_{\mathrm{i}}+\mathrm{e}_{\mathrm{ij}}$

Where:

Yij = the observation of performance or carcass traits for $\mathrm{ij}^{\text {th }}$ lamb;

$\mu=$ general mean, common element to all observations;

$\mathrm{Si}=$ the fixed effect due to the $\mathrm{i}^{\text {th }}$ management systems $(I=1,2)$;

eij= Random error associated with the individual observation and assumed NID $\cong\left(0, \sigma_{2 \mathrm{e}}\right)$.
Tests of significance for the differences between means were performed according to Duncan (1955).

\section{RESULTS AND DISCUSSION}

\section{A-Lambs performance:}

Results of least squares means and standard errors of the studied measures are presented in Table 3. Lambs of Intensive management system exhibited higher final body weight, total dry matter feed intake, average daily gain and economical feed efficiency than semi-intensive management system it may be due to high management care in intensive system. Management system affected significantly $(\mathrm{P}<0.01$ and $\mathrm{P}<0.05)$ final weight, average daily 
gain, total dry matter feed intake and economical feed efficiency, respectively. Results obtained agree with those of Dimsoski et al. (1999),
Kuldeep et al. (2006), Das et al. (2008), Munir et al. (2008), Carrasco et al. (2009) and Barham et al. (2013).

Table 3. Least-squares means and standard errors (LSM \pm SE) of lamb's performance

\begin{tabular}{lcccc}
\hline Items & $\begin{array}{c}\text { Intensive } \\
\text { management } \\
\text { system }\end{array}$ & $\begin{array}{c}\text { Semi-intensive } \\
\text { management } \\
\text { system }\end{array}$ & MSt & MSE \\
\hline Initial lambs body weight (KG) & $23.50 \pm 0.77$ & $22.60 \pm 0.77$ & 4.05 & 6.05 \\
final lambs body weight (KG) & $43.50 \pm 1.15 \mathrm{a}$ & $38.80 \pm 1.15 \mathrm{~b}$ & $110.45^{* *}$ & 13.33 \\
Average daily gain (KG) & $0.238 \pm 0.010 \mathrm{a}$ & $0.192 \pm 0.010 \mathrm{~b}$ & $0.0105^{* *}$ & 0.001 \\
Total feed intake of dry matter & $115.57 \pm 2.05 \mathrm{a}$ & $108.92 \pm 2.05 \mathrm{~b}$ & $221.11^{*}$ & 42.22 \\
concentrate mixture(KG) & $6.32 \pm 0.31$ & $7.06 \pm 0.31$ & 2.78 & 1.01 \\
$\begin{array}{l}\text { Feed conversion (feed/gain) } \\
\text { Economical feed efficiency } \\
\text { (Benefit/cost ratio) }\end{array}$ & $1.43 \pm 0.06 \mathrm{a}$ & $1.24 \pm 0.06 \mathrm{~b}$ & $0.178^{*}$ & 0.037 \\
\hline
\end{tabular}

$*=\mathrm{p}<0.05, * *=\mathrm{p}<0.01, * * *=\mathrm{p}<0.001$.

$\mathrm{a}, \mathrm{b}$ Means within any classification, followed by different letters are significantly different $(\mathrm{p}<0.05)$

$\mathrm{MSt}=$ Mean Squares or management systems, MSE = Mean Squares for error.

\section{b- Lambs Carcass Traits:}

Lambs of intensive management system exceed in hot carcass weight, dressing $\%$, first cuts and second cuts lambs of semi-intensive management system as showed in Table 4. There is significant variations $(\mathrm{P}<0.001)$ between management systems in hot carcass weight, dressing\%, first cuts and second cuts of lambs carcass. Similar results were obtained by various authors Pal et al. (1997), Dimsoski et al. (1999), Das et al. (2008), Yilmaz et al. (2009) and Hanekom (2010) .
Intensive management system lambs had heavier carcass cuts weight than semi-intensive management system as showed in table 5. There are significant $(\mathrm{P}<0.05, \mathrm{P}<0.01$ and $\mathrm{P}<0.001)$ between management systems in carcass cuts weight. There were partially agreement between the present results and which reported by Karim et al. (2007), Archimede et al.(2008), Carrasco et al.(2009), Ekiz et al.(2009) and Yilmaz et al.(2009).

Table 4. Least square means and standard errors (LSM \pm SE) of lamb's carcass traits at the end of feeding experiment

\begin{tabular}{lcccc}
\hline Items & $\begin{array}{c}\text { Intensive } \\
\text { management system }\end{array}$ & $\begin{array}{c}\text { Semi-intensive } \\
\text { management } \\
\text { system }\end{array}$ & MSt & MSE \\
\hline Hot carcass weight $(\mathrm{KG})$ & $23.67 \pm 0.61 \mathrm{a}$ & $16.68 \pm 0.61 \mathrm{~b}$ & $146.44^{* * * *}$ & 2.303 \\
Dressing percentage (\%) & $67.44 \pm 0.44 \mathrm{a}$ & $62.59 \pm 0.44 \mathrm{~b}$ & $70.567 * * *$ & 1.175 \\
Prime cuts weight (KG) & $16.41 \pm 0.54 \mathrm{a}$ & $12.13 \pm 0.54 \mathrm{~b}$ & $54.826^{* * *}$ & 1.787 \\
Second cuts weight $(\mathrm{KG})$ & $6.42 \pm 0.22 \mathrm{a}$ & $4.57 \pm 0.22 \mathrm{~b}$ & $10.267 * * *$ & 0.294 \\
\hline
\end{tabular}

$*=\mathrm{p}<0.05, * *=\mathrm{p}<0.01, * * *=\mathrm{p}<0.001$.

a, b Means within any classification, followed by different letters are significantly different $(\mathrm{p}<0.05)$

$\mathrm{MSt}=$ Mean Squares for management systems, MSE= Mean Squares for error.

Table 5. Least squares means and standard error (LSM \pm SE) of lamb's carcass cuts

\begin{tabular}{lcccc}
\hline $\begin{array}{c}\text { Carcass cuts weight } \\
\text { (KG) }\end{array}$ & $\begin{array}{c}\text { Intensive management } \\
\text { system }\end{array}$ & $\begin{array}{c}\text { Semi-intensive } \\
\text { management system }\end{array}$ & MSt & MSE \\
\hline Round & $6.40 \pm 0.16 \mathrm{a}$ & $4.92 \pm 0.16 \mathrm{~b}$ & $6.526^{* * *}$ & 0.157 \\
Loin & $2.77 \pm 0.11 \mathrm{a}$ & $1.83 \pm 0.11 \mathrm{~b}$ & $2.632^{* * *}$ & 0.074 \\
Rack & $3.66 \pm 0.25 \mathrm{a}$ & $2.41 \pm 0.25 \mathrm{~b}$ & $4.687^{* *}$ & 0.375 \\
Shoulder & $3.57 \pm 0.10 \mathrm{a}$ & $2.96 \pm 0.10 \mathrm{~b}$ & $1.122^{* *}$ & 0.069 \\
Nick & $1.47 \pm 0.08$ & $1.32 \pm 0.08$ & 0.067 & 0.047 \\
Brisket & $0.90 \pm 0.11$ & $1.06 \pm 0.11$ & 0.080 & 0.079 \\
Flank & $1.23 \pm 0.21 \mathrm{a}$ & $0.52 \pm 0.21 \mathrm{~b}$ & $1.526^{*}$ & 0.270 \\
Tail & $2.81 \pm 0.21 \mathrm{a}$ & $1.66 \pm 0.21 \mathrm{~b}$ & $3.967^{*}$ & 0.285 \\
\hline
\end{tabular}

$*=\mathrm{p}<0.05, * *=\mathrm{p}<0.01, * * *=\mathrm{p}<0.001$.

$\mathrm{a}, \mathrm{b}$ Means within any classification, followed by different letters are significantly different $(\mathrm{p}<0.05)$

$\mathrm{MSt}=$ Mean Squares for management systems, MSE $=$ Mean Squares for error . 
Some internal organs of lambs carcass in intensive management system group were heavier than that in semi-intensive management system group as showed in table 5. Management systems showed a significant $(\mathrm{P}<0.05, \mathrm{P}<0.01$ and $\mathrm{P}<0.001)$ between carcass cuts weight. There were partially agreement among the present results and that reported by Karim et al. (2007), Archimede et al. (2008), Carrasco et al. (2009) and Yilmaz et al. (2009).

Table 6. Least squares means and standard error (LSM \pm SE) of lamb's carcass offals

\begin{tabular}{lcccc}
\hline $\begin{array}{l}\text { Carcass offals weight } \\
\text { (KG) }\end{array}$ & $\begin{array}{c}\text { Intensive management } \\
\text { system }\end{array}$ & $\begin{array}{c}\text { Semi-intensive } \\
\text { management system }\end{array}$ & MSt & MSE \\
\hline Skin & $5.06 \pm 0.16 \mathrm{a}$ & $4.25 \pm 0.16 \mathrm{~b}$ & $1.984^{* *}$ & 0.168 \\
Heads & $2.68 \pm 0.10 \mathrm{a}$ & $2.12 \pm 0.10 \mathrm{~b}$ & $0.952^{* *}$ & 0.064 \\
Legs & $0.88 \pm 0.04$ & $0.81 \pm 0.04$ & 0.016 & 0.010 \\
heart & $0.16 \pm 0.02$ & $0.15 \pm 0.02$ & 0.0004 & 0.003 \\
Kidneys & $0.21 \pm 0.01 \mathrm{a}$ & $0.17 \pm 0.01 \mathrm{~b}$ & $0.0044^{*}$ & 0.0006 \\
Liver & $0.83 \pm 0.05$ & $0.70 \pm 0.05$ & 0.0560 & 0.0169 \\
Lung & $0.78 \pm 0.05$ & $0.68 \pm 0.05$ & 0.030 & 0.017 \\
Spleen & $0.12 \pm 0.01$ & $0.10 \pm 0.01$ & 0.0018 & 0.0008 \\
Tests & $0.41 \pm 0.02 \mathrm{a}$ & $0.30 \pm 0.02 \mathrm{~b}$ & $0.038^{* *}$ & 0.0045 \\
Digestion tracts full & $8.04 \pm 0.19 \mathrm{a}$ & $6.92 \pm 0.19 \mathrm{bb}$ & $3.785^{* *}$ & 0.225 \\
Digestion tracts empty & $2.30 \pm 0.10$ & $2.13 \pm 0.10$ & 0.0800 & 0.0653 \\
Rumen content & $5.74 \pm 0.16 \mathrm{a}$ & $4.78 \pm 0.16 \mathrm{~b}$ & $2.7648^{* *}$ & 0.157 \\
\hline
\end{tabular}

$*=\mathrm{p}<0.05, * *=\mathrm{p}<0.01, * * *=\mathrm{p}<0.001$.

$\mathrm{a}, \mathrm{b}$ Means within any classification, followed by different letters are significantly different $(\mathrm{p}<0.05)$

MSt $=$ Mean Squares for management systems, MSE $=$ Mean Squares for error.

\section{CONCLUSION}

Present results concluded that, the male Ossimi lambs under intensive management system gained more body weight, average daily gain, economical feed efficiency and carcass traits than that of lambs under semi-intensive management system.

\section{REFERENCES}

Ali, M. M. M., 2007. Growth curve and carcass characteristics of Ossimi and Rahmini lambs during the first year of age. M. Sc. Faculty of Agriculture, Cairo University.

Archimede, H., P. Pellonde, P. Despois, T. Etienne and G. Alexandre, 2008. Growth performances and carcass traits of Ovin Martinik lambs fed various ratios of tropical forage to concentrate under intensive conditions. Small Ruminant Research vol. 75 pages $162-170$.

Barham, G.S., M. H. Baloch, A. H. Nizamani, M. Khaskheli, G. Khaskheli, S.A. Pirzado, A.S. Magsi, H. Soomro and S. Fazilani, 2013. Effect of management systems on growth and conformation of male lambs of Kachhi and Kooka sheep. International journal of Plant and Animal Sciences vol. 1(6): 64-69.

Carrasco, S., G. Ripoll, A. Sanz, J. ÁlvarezRodríguez, B. Panea, R. Revilla and M. Joy , 2009. Effect of feeding system on growth and carcass characteristics of Churra

Tensina light lambs. Livestock Science vol. 121 pages 56-63.
DAS, A. K., G. DASS and N. P. SINGH , 2008. Growth, carcass characteristics and meat quality of Muzaffarnagari lambs at various stages under intensive and semiintensive management. Indian Journal of Animal Sciences, Vol. 78 No. 5.

Dimsoski, P, J. J. Tosh, J. C. Clay and K. M. Irvin, 1999. Influence of management system on litter size, lamb growth and carcass characteristics in sheep. Journal of Animal Sciencevol. 77 pages 1037-1043.

Duncan, D. B., 1955. Multiple range and multiple $\mathrm{F}$ tests. Biometrics, 11: 1-42.

Ekiza , A. Yilmaz, A. Ozcan, B. Kaptan, B. Hanoglu, B. Erdogan, and H. Yalcintan , 2009. Carcass measurements and meat quality of Turkish Merino, Ramlic, Kivircik, Chios and Imroz lambs raised under an intensive production system. Meat Science vol. 82 Pages 64-70.

El-Mahdy, M. R., H. K.Hamdia, M. H. M. Mahmoud and A. H. A. Gomaa, 2000. Study of carcass quality in local sheep. Annals of Agric. Sci., Moshtohor, Vol. 38(1): 101-127.

Hanekom, Y., 2010. The effect of extensive and intensive production systems on the meat quality and carcass characteristics of Dohne Merino lambs. M. Sc. Faculty of Agriculture Sciences. Stellenbosch University. South Africa.

Hassan, T. M. M., 2011. Study of some factors affecting productive traits of sheep under Egyptian conditions. Ph.D. Faculty of Agriculture, Banha University.

Karim, S.A., P. Kuldeep, S. Kumar and V.K. Singh, 2007. Carcass traits of Kheri lambs 
maintained on different system of feeding management. Meat Science vol. 76 pages 395-401.

Kuldeep, P., S. A. Karim, S. L. Sisodia and V. K. Singh, 2006. Relative economics of lamb rearing for mutton production under extensive, semi intensive and intensive system of feeding management. Indian Journal of Small Ruminants vol. (12) issue 1 P 67-73.

N.R.C., 1985.Nutrient requirements of sheep, ( $6^{\text {th }}$ Ed.) National Academy Press,

Washington, D.C.

MUNIR M., A.W. JASRA and S. RAFIQUE, 2008. Lamb production under different systems of management on range lands of Balochistan. Pakistan Vet. J. Vol. 28(2): 6870.
PAL, U. K., M. K. AGNIHOTRI and N. K. SINHA, 1997. Carcass traits of Muzaffarnagari lambs under intensive and semi-intensive management systems. Indian Journal of Animal Sciences, Vol. (67) No.8.

S.A.S., 2004. SAS Procedure Guide"version 9 Ed”. SAS Institute Inc., Cary, NS, USA.

Yehia, M. M., 2006. Improvement of sheep productivity through hormonal control and management system. M. Sc. Faculty of Agriculture, Ain Shams University.

Yilmaz, A., B. Ekiz, M. Ozcan, C. Kaptan, H. Hanoglu, I. Erdogan and O. Kocak, 2009. Carcass traits of improved and indigenous lamb breeds of North-Western Turkey under an intensive production system. Italian Journal Animal Science vol. 8, 663-675.

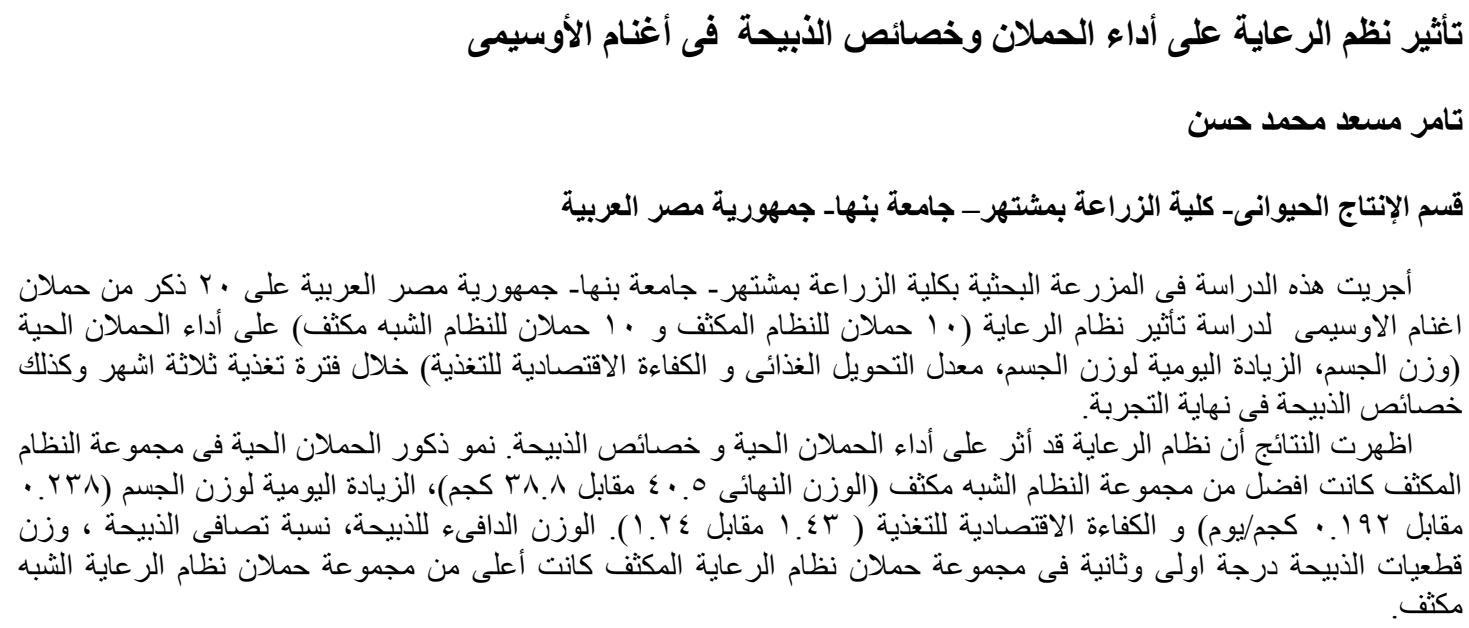

